ISSN 1978-2071 (Print); ISSN 2580-5967 (Online)

Jurnal IImiah Kedokteran Wijaya Kusuma 6 (1) : 34-44

\title{
Penyebab Perubahan Ketebalan Carotid Intima-Media
}

\author{
Budi Arief Waskito \\ Bagian IImu Penyakit Dalam Fakultas Kedokteran Universitas Wijaya Kusuma Surabaya \\ e-mail: hernifile@gmail.com
}

\begin{abstract}
Abstrak
Aterosklerosis menyebabkan morbiditas dan mortalitas yang signifikan. Carotid intima-media thickness (CIMT) dapat memprediksi timbulnya kardiovaskuler dan stroke iskemik di masa depan. CIMT, pengukuran aterosklerosis, ditentukan secara in vivo menggunakan ultrasound karotis. CIMT berhubungan dengan faktor risiko kardiovaskuler tradisional seperti usia, jenis kelamin, ras, kebiasaan merokok, konsumsi alkohol, kebiasaan olahraga, tekanan darah, dislipidemia, pola diet, obat yang digunakan, glycemia, hiperurisemia, paramater antropometrik yang berhubungan dengan obesitas. Selain itu, CIMT juga berhubungan dengan faktor risiko yang baru (novel), yaitu genotip, paramater antropometri kardiovaskuler, rheumatoid arthritis, penyakit imunologi, inflammatory cytokines, lipid peroxidation, paramater antropometri chemocyte, penyakit infeksi, vitamin D, matrix metalloproteinases, dan penyakit lainnya.
\end{abstract}

Kata kunci: Ultrasound, Aterosklerosis, Pembuluh perifer, Carotid intima-media thickness, Penyakit kardiovaskuler dan cerebrovaskuler, faktor risiko

\section{Cause of Change on Carotid Intima-media Thickness}

\begin{abstract}
Atherosclerosis causes significant morbidity and mortality. Carotid intima-media thickness (CIMT) can predict the onset of cardiovascular and ischemic stroke in the future. CIMT, the measurement of atherosclerosis, is determined in vivo using carotid ultrasound. CIMT is associated with traditional cardiovascular risk factors such as age, sex, race, smoking habits, alcohol consumption, exercise habits, blood pressure, dyslipidemia, dietary patterns, medications used, glycemia, hyperuricemia, anthropometric parameters associated with obesity. In addition, CIMT is also associated with novel risk factors, ie genotypes, cardiovascular anthropometry parameters, rheumatoid arthritis, immunologic diseases, inflammatory cytokines, lipid peroxidation, chemocyte anthropometric parameters, infectious diseases, vitamin $\mathrm{D}$, matrix metalloproteinases, and other diseases.
\end{abstract}

Keywords: Ultrasound, Aterosclerosis, Pheripheral Vascular, Carotid intima-media thickness, Cardiovasculer and Cerebrovasculer, risk factors.

\section{PENDAHULUAN}

Aterosklerosis merupakan penyebab patologis penting penyakit kardiovaskuler dan cerebrovaskuler yang menyebabkan mortalitas dan berdampak pada morbiditas. Untuk itu, fokus riset ditujukan pada prevensi dini penyakit kardiovaskuler dan penyakit cerebrovaskuler. Aterosklerosis preklinis berhubungan dengan jumlah penyakit jantung koroner dan stroke yang tinggi. Hasil penelitian menunjukkan bahwa ultrasonografi karotis (1) lebih sensitif daripada coronary artery calcification score (CACS) untuk mendeteksi aterosklerosis subklinis. Ultrasonografi carotid intima-media thickness (CIMT) merupakan metode yang mudah untuk mendeteksi aterosklerosis subklinis (2). CIMT meningkat secara signifikan pada pasien yang mempunyai plak, merupakan marker kerusakan organ subklinis dan prediktor independent kejadian kardiovaskuler dan serebrovaskuler. Beberapa 
studi melaporkan bahwa ada hubungan antara CIMT dengan faktor risiko di atas. Namun sejauh ini, konsep faktor risiko CIMT masih belum jelas. Disini dikombinasikan antara faktor risiko CIMT, termasuk faktor risiko tradisional berupa usia, jenis kelamin, kebiasaan merokok, konsumsi alkohol, tekanan darah, lemak darah, gula darah, gaya hidup dan lain-lain; namun demikian, faktor risiko lama tidak dapat menjelaskan semua risiko. Studi terbaru mendapatkan bahwa $>60 \%$ kasus CIMT tidak dapat dijelaskan dengan demografi dan faktor risiko kardiovaskuler tradisional, dan memerlukan penelitian faktor risiko novel, yang menunjukkan faktor risiko lain untuk aterosklerosis karotis. Faktor risiko novel ini didapatkan dari penelitian terbaru dan belum dikenali secara luas sebagai faktor risiko, seperti gaya hidup, tekanan pekerjaan, penyakit tertentu, faktor risiko genetik untuk penyakit tertentu, dan lingkungan novel, parameter fisiologis dan patologis. Identifikasi faktor risiko novel yang berhubungan dengan CIMT sangat membantu untuk prevensi dan terapi aterosklerosis dini (3).

\section{Hubungan antara CIMT dengan faktor risiko kardiovaskuler tradisional}

\section{Hubungan antara CIMT dan usia, jenis kelamin, ras, kebiasaan merokok, konsumsi alkohol dan kebiasaan olahraga}

Usia, jenis kelamin, ras, kebiasaan merokok, dan kebiasaan konsumsi alkohol berperan penting pada aterosklerosis. CIMT merupakan marker penting untuk risiko kardiovaskuler pada dewasa usia < 45 tahun yang belum ada indikasi untuk skrining risiko kardiovaskuler standard. Usia gestasional tidak mempengaruhi CIMT dan peningkatan usia berhubungan dengan CIMT berupa penurunan fungsi diastolik kardiak hanya pada perempuan(4). CIMT sama antara laki-laki Asia Selatan dengan Eropa. Walapun pada laki-laki, CIMT nya lebih besar daripada perempuan, perbedaannya tidak signifikan secara statistik setelah penyesuaian diameter karotis. Perbedaan jenis kelamin, berhubungan dengan faktor risiko masa kanak-kanak dengan dewasa dan aterosklerosis subklinis(5). Selain itu, CIMT juga berhubungan dengan kebiasaan merokok dan kebiasaan konsumsi alkohol pada laki-laki. Ada pula hasil penelitian yang sebaliknya, yaitu konsumsi alkohol baik untuk CIMT pada laki-laki dan efek alkohol pada CIMT kemungkinan disebabkan karena faktor lipid. Kebiasaan olahraga, terutama aerobik, penting pada prevensi aterosklerosis. Hasil penelitian pada orang Afrika Amerika, menunjukkan bahwa melakukan aerobik selama 8 minggu atau 6 minggu dapat memperbaiki struktur dan fungsi vaskuler(6). Kapasitas pengambilan oksigen maksimal disesuaikan dengan berat yang berbanding terbalik dengan CIMT. Tetapi walaupun kebiasaan olahraga dapat memperbaiki profil risiko kardiovaskuler, ia tidak menurunkan kekuatan hubungan antara aterosklerosis karotis dengan usia dan faktor risiko kardiovaskuler(7). Walaupun demikian, penentuan efek olahraga yang berbeda pada CIMT masih memerlukan penelitian lebih lanjut.

\section{Hubungan antara CIMT dengan tekanan Darah}

Tekanan darah yang tinggi merupakan faktor risiko penyakit kardiovaskuler dan penyakit cerebrovaskuler. Hubungan antara CIMT dengan berbagai tipe tekanan darah yang abnormal pada berbagai populasi masih belum diketahui. Tekanan darah yang tinggi merupakan penentu utama CIMT. Tekanan darah sistolik, tekanan darah diastolik, pulse pressure (PP) yang tinggi, tekanan darah siang hari, peningkatan tekanan darah dari masa kanak-kanan sampai dewasa yang persisten, variabilitas tekanan darah diastolik saat pemeriksaan pada populasi normotensi dan variabilitas tekanan darah sistolik (SBPV) yang juga mempunyai hubungan positif dengan CIMT(8). SBP (tekanan darah sistolik) merupakan mekanisme patologis utama yang tidak langsung mempengaruhi CIMT melalui jalur hemodinamik. Risiko ini menurun apabila tekanan darah yang meningkat saat masa kanak-kanak berkurang setelah dewasa. Hubungan antara variabilitas tekanan darah (BPV) dengan cabang kiri carotid artery-intimamedia thickness/jumlah plak lebih kuat daripada cabang kanan carotid artery-intimamedia thickness/jumlah plak. Peningkatan CIMT pada subyek hipertensi Congolese diidentifikasi menggunakan marker remodelling arterial yang berhubungan dengan riwayat panjang hipertensi yang tidak terkontrol 
daripada aterosklerosis dini(9). Pada laki-laki Afrika yang hipertensi, CIMT berhubungan negatif dengan kadar glutathione (GSH), hal ini menunjukkan bahwa CIMT kemungkinan berkontribusi pada kenaikan kadar GSH pada perkembangan aterosklerosis subklinis. Secara ringkas, semua tipe hipertensi merupakan penyebab utama aterosklerosis preklinis. Jadi, untuk prevensi aterosklerosis dini, perlu dilakukan pemeriksaan untuk mengontrol hipertensi.

\section{Hubungan antara CIMT dengan dislipidemia, pola diet, dan terapi obat untuk menurunkan risiko}

Perubahan gaya hidup sehat dan tidak sehat selama masa dewasa muda berhubungan dengan penurunan dan peningkatan risiko, untuk terjadinya aterosklerosis subklinis pada usia pertengahan. Dislipidemia merupakan faktor penting terjadinya aterosklerosis dan berhubungan dengan CIMT. Analisis regresi menunjukkan bahwa mean dan maximum CIMT (CIMT[max]) secara independen dipengaruhi oleh usia, kadar kreatinin, dan kadar kolesterol non-high density lipoprotein (HDL)(10). Secara khusus, pasien dengan familial hypercholesterolemia $(\mathrm{FH})$ risikonya meningkat untuk penyakit kardiovaskuler premature. Anak-anak hiperkolesterolemia dan pasien dengan FH mempunyai CIMT yang lebih tinggi. Hasil dari meta-analisis CIMT memperkuat kejadian perkembangan aterosklerosis dini pada anak-anak dengan FH. Kadar kolesterol LDL sirkulasi berhubungan dengan CIMT dan kadar tinggi oxidized LDL (OxLDL) berhubungan secara signifikan dengan progresifitas dan peningkatan kadar CIMT. Kadar kolesterol HDL yang rendah atau kadar relatif HDL subklas $3 b$ dan perubahan proporsi partikel HDL kecil, secara signifikan berhubungan dengan peningkatan CIMT dan dengan adanya plak karotis. Pada perempuan, IMT(max) berhubungan negatif secara signifikan dengan kolesterol HDL. Pada kelompok statin, kadar kolesterol HDL berhubungan dengan CIMT; Pada kelompok terapi kombinasi, hanya kadar kolesterol HDL yang berhubungan secara significant dengan CIM T(11).

Apoliproprotein juga merupakan faktor risiko penting untuk aterosklerosis. Diantaranya, apolipoprotein B(apoB) [33] and ApoB/ApoA1 berhubungan secara positif signifikan dengan CIMT, dan tidak adanya atau kadar erythrocyte-bound apoB yang sangat rendah berhubungan dengan aterosklerosis klinis dan subklinis. Sebaliknya, studi lain menemukan bahwa genotip ApoE dan CIMT tidak berhubungan dan ApoA1 mempunyai hubungan terbalik dengan CIMT(12). Apakah perubahan pola diet mempengaruhi risiko aterosklerosis dini masih diperdebatkan. Satu studi yang hasilnya tidak menunjukkan adanya hubungan antara pola diet dengan IMT atau plak, dan asupan tinggi versus rendah protein pada bayi tidak mempengaruhi CIMT selama 5 tahun. Beberapa studi menunjukkan hasil bahwa diet Mediterranean mempunyai efek protektif pada sistem kardiovaskuler karena ketaatan yang rendah pada diet M editerranean menunjukkan adanya peningkatan risiko aterosklerosis subklinis. Selain itu, 12 bulan intervensi diet Mediterranean menyebabkan penurunan signifikan CIMT. Intervensi pada kolesterol LDL yang rendah dari rentang suboptimal sampai optimal memperlihatkan manfaat signifikan. Pemberian atorvastatin, rosuvastatin dan fuvastatin akan memperlambat atau menurunkan progresifitas CIMT, terapi kolesterol dan antihipertensi yang intensif, bersama dengan penurunan lemak sentral dapat dipertimbangkan untuk menjadi terapi strategis pada pasien usia muda dengan $\mathrm{FH}$ untuk mencegah aterosklerosis dan untuk meningkatkan kekakuan arteri(13). Pada lakilaki dengan CHD dan kadar Lp(a) yang tinggi, pemberian atorvastatin menyebabkan penurunan CIMT rata-rata 0,06 mm selama 6 bulan. Pemberian statin yang adekuat dapat memperlambat aterosklerosis karotis pada $\mathrm{FH}$ independent of $L p(a)$ levels(14). Karenanya, CIMT berhubungan dengan dislipidemia dan dysapoliproprotein tetapi tidak berhubungan dengan asupan protein. Terapi kolesterol yang intensif dapat digunakan untuk menurunkan progresifitas CIMT pada pasien dengan risiko tinggi.

\section{Hubungan antara CIMT dengan glycemia dan hiperurisemia}

Glycemia dan hiperurisemia juga merupakan faktor risiko penting untuk aterosklerosis yang berhubungan dengan penyakit kardiovaskuler dan cerebrovaskuler. Status glycemic berhubungan dengan semua stadium aterosklerotik karotis; dari tanda awal, yang diperlihatkan oleh IMT; sampai stadium intermediat, seperti pada adanya plak karotis; 
aterosklerosis lanjut, ditandai dengan adanya stenosis karotis(15). Glycemia, termasuk diabetes melitus tipe 2 (T2DM) dan impaired fasting glucose (IFG), merupakan penentu utama independent dari CIMT pada pasienpasien hiperglikemi. Kadar insulin, HOMA-IR index, kadar IGF-1 total dan peningkatan resistensi insulin berhubungan secara positif dengan CIMT; resistensi insulin pada dewasa muda dengan obesitas dapat memperburuk perubahan CIMT dan menyebabkan berkembangnya aterosklerosis dini. Kadar hemoglobin Alc yang lebih rendah juga diidentifikasi sebagai faktor risiko signifikan untuk aterosklerosis karotis pada laki-laki Jepang lanjut usia di pedesaan(16). Kadar plasma obestatin yang rendah berhubungan dengan aterosklerosis dini pada pasien dengan T2DM via peningkatan CIMT, mempertimbangkan bahwa peningkatan kadar plasma obestatin dapat melindungi pasien T2DM terhadap terjadinya aterosklerosis karotis. Walaupun ada hubungan antara tingkat CIMT dengan risiko vaskuler pada subyek dengan diabetes, tetapi tidak ada hubungan antara perubahan CIMT dengan risiko vaskuler(17). Namun, pasien dengan T2DM, perubahan gaya hidup selama 6 bulan dapat memperbaiki kontrol glycemic dan menurunkan progresifitas CIMT. Selain itu, hiperurisemia merupakan faktor risiko independent untuk penyakit kardiovaskuler dan penyakit cerebrovaskuler. Hiperurisemia berhubungan terbalik dengan aterosklerosis karotis subklinis pada laki-laki; namun, hiperurisemia berhubungan dengan kerusakan renal merupakan marker signifikan untuk aterosklerosis karotis subklinis pada laki-laki dan perempuan(18). Oleh karena itu, intervensi yang tepat waktu untuk glycemia dan hiperurisemia dapat memperlambat timbul nya aterosklerosis dini. Ketepatan waktu ini harus menjadi fokus utama para klinisi.

\section{Hubungan antara CIMT, parameter antropometri yang berhubungan dengan obesitas, obesitas dan penyakit yang berhubungan dengan obesitas.}

Parameter antropometri yang berhubungan dengan obesitas, obesitas dan penyakit yang berhubungan dengan obesitas, termasuk nonalcoholic fatty liver disease (NAFLD), alcoholic fatty liver disease (AFLD) dan polycystic ovary syndrome (PCOS), dilaporkan mempunyai hubungan dengan peningkatan risiko kardiovaskuler dan serebrovaskuler.

\section{Hubungan antara CIMT dengan parameter antropometri yang berhubungan dengan obesitas}

Berbagai parameter antropometri yang berhubungan dengan obesitas digunakan untuk evaluasi hubungan antara obesitas dengan penyakit yang berhubungan dengan aterosklerosis. Penelitian menunjukkan bahwa CIMT yang besar berhubungan dengan parameter antropometri yang berhubungan dengan obesitas, antara lain body mass index (BMI), lingkar pinggang, waist-to-hip ratio (WHR) dan WHtT. Selain itu, hubungan antara CIMT dengan distribusi lemak masih belum diketahui. Ketebalan visceral adipose tissue (VAT)(19), bukan ketebalan lemak subkutan, berhubungan dengan IMT pada laki-laki dan pasien yang menjalani dialisis peritoneal. Peningkatan volume lemak epicardial dan periaortic root fat (PARF) merupakan faktor risiko independent untuk peningkatan CIMT. Namun ada penelitian yang hasilnya kontradiksi yaitu CIMT tidak berhubungan dengan obesitas viseral. Jadi, diperlukan studi prospektif untuk menentukan adanya hubungan antara CIMT dengan obesitas viseral. Selain itu, riset terbaru menunjukkan hasil bahwa mean CIMT bervariasi di antara fenotip obesitas; nilai CIMT lebih tinggi dan mempunyai hubungan positif dengan plak karotis dan aterosklerosis karotis yang didapatkan hanya pada subtipe obesitas abnormal metabolic(20). Hasil yang kontradiksi ini menunjukkan bahwa obesitas tidak mempengaruhi parameter vaskuler yang berhubungan dengan aterosklerosis dini, termasuk CIMT pada perempuan dengan faktor risiko minor kardiovaskuler. Diperlukan studi selanjutnya untuk mencari hubungan antara perbedaan distribusi lemak dengan CIMT.

\section{Hubungan antara CIMT dengan obesitas dan penyakit yang berhubungan dengan obesitas}

Studi terbaru menunjukkan bahwa kelebihan berat badan, obesitas dan penyakit yang berhubungan dengan obesitas, termasuk NAFLD, AFLD dan COS, berhubungan dengan CIMT. Kelebihan berat badan, obesitas dan morbiditas pasien obesitas sama dengan nilai 
CIMT dan small artery reactivity index. Pasien dengan NAFLD dan AFLD, CIMT meningkat signifikan, dan hubungan antara NAFLD dengan aterosklerosis subklinis merupakan faktor risiko tradisional independent. ALD juga dapat mempercepat peningkatan premature CIM T via mekanisme resistensi insulin dan fungsi liver yang abnormal, termasuk ALT dan GGT, pada pasien dengan NAFLD dan NASH. Usia dan faktor metabolik juga berhubungan dengan penebalan CIM pada pasien ALD. PCOS merupakan penyakit kandungan, dan obesitas independent, pasien dengan PCOS, CIMT nya bisa meningkat akibat langsung dari kelebihan androgen(21), hal ini menunjukkan bahwa hiper-androgenism dapat meningkatkan risiko aterosklerosis dan kardiovaskuler. Namun, ada pula studi yang hasilnya berbeda. Jadi diperlukan studi lebih lanjut untuk mencari hubungan yang tepat antara CIMT dengan NAFLD, AFLD, dan PCOS.

\section{Hubungan antara CIMT dengan faktor risiko novel}

\section{Hubungan antara CIMT dengan keturunan dan genotip tertentu}

Keturunan dan genetik berperan penting pada aterosklerosis. Namun masih belum diketahui apakah CIMT berhubungan dengan keturunan dan genotip tertentu. Suatu studi menunjukkan adanya gen-gen yang berbeda yang mempengaruhi variasi CIMT dan lingkar pinggang. Lokus genetik tertentu yang menentukan fungsi paru-paru manusia juga mempengaruhi CIMT dan kecenderungan $C A D(22)$. Hubungan yang paling kuat didapatkan pada pemendekan telomere pada dewasa usia 53 dan 60-64 tahun dan CIM T pada dewasa usia 60-64 tahun. Namun demikian, lokus kromosom 9p21 tidak mempengaruhi risiko CAD melalui mekanisme yang juga mempengaruhi CIMT atau yang menginduksi perubahan dini pada flow-mediated dilatation (FMD)(23). Haptoglobin (Hp) 2-2 genotype merupakan prediktor signifikan aterosklerosis dini dan berhubungan dengan peningkatan CIMT pada anak-anak dengan beta-thalassemia major. Single nucleotide polymorphisms (SNPs) pada 7-dehydrocholesterol reductase/NAD synthetase-1 interacted dengan diabetes tipe 2 mempengaruhi progresifitas CIMT yang tidak tergantung pada kadar 25(OH)D dan adanya faktor risiko(24). Jadi, tidak didapatkan adanya hubungan yang signifikan antara genotip berbagai SNPs dan CIMT pada 846 individu. Selain itu, pasien dengan Osteopontin genotip $66 \pi$, terutama yang tanpa MetS, CIM-nya lebih tebal(25). Untuk itu, hubungan antara CIMT dengan keturunan masih memerlukan penelitian lebih lanjut guna menentukan terapi yang lebih baik.

\section{Hubungan antara CIMT dengan parameter antropometri kardiovaskuler}

Hasil studi terbaru menyatakan bahwa perubahan jantung-dan-arteri tertentu mungkin berhubungan dengan CIMT. Perubahan ini menentukan komplikasi T2DM. Studi mengenai hubungan antara peningkatan CIMT dengan tingginya kejadian cardiac autonomic neuropathy (CAN), tingkat coronary artery calcification (CAC)(26). Namun, variant coronary artery disease (CAD) tidak berhubungan dengan CIMT dan tidak memediasi risiko atherothrombosis melalui faktor risiko yang telah diketahui. Selain itu, menurunnya FMD pada berbagai keadaan dan penyakit dapat menyebabkan menebalnya CIM(27). Mekanisme pastinya masih belum diketahui dan memerlukan penelitian lebih lanjut.

\section{Hubungan antara CIMT dengan rheumatoid arthritis (RA) dan penyakit imunologi}

Pasien dengan RA, Behcet disease (BD), systemic lupus erythematosus (SLE), primary Sjogren syndrome, dan psoriatic arthritis (PSA) mempunyai risiko aterosklerosis lebih tinggi dan berhubungan dengan meningkatnya risiko kardiovaskuler dan penyakit vaskuler subklinis. RA berhubungan dengan peningkatan risiko penyakit kardiovaskuler (CVD) dan aterosklerosis subklinis(28). Namun, ada hasil studi yang berlawanan, yaitu melaporkan bahwa RA tidak menyebabkan penebalan CIM. Hasil observasi klinis menunjukkan bahwa RA berhubungan dengan peningkatan CIMT. Mekanisme penebalan CIM yang berhubungan dengan RA antara lain, peningkatan kadar Ox$L D L$, aktivitas VWF, serum mannose-binding lectin dan PWV serta peningkatan kadar marker inflamasi seperti IL-17, dan CR dan kadar rendah $\hat{I}^{2}$-carotene, vitamin $\mathrm{D}, \mathrm{CD} 34+$ cells dan NO2. Psoriasis berhubungan dengan 
peningkatan mean CIMT dan meningkatkan beban aterosklerosis subklinis(29). Aterosklerosis subklinis yang lebih berat didapatkan pada pasien dengan PsA dibandingkan dengan pasien dengan cutaneous psoriasis tanpa arthritis (PsC). Penyebab aterosklerosis pada PsA antara lain marker percepatan aterosklerosis seperti ox-LDLs dan NO serta disfungsi endotelial, lamanya penyakit PsA, makin parahnya penyakit kulit dan peningkatan marker inflamasi, namun aterosklerosis pasa PsA tidak berhubungan dengan faktor risiko tradisional CV. Lebih lanjut, peningkatan CIMT berhubungan dengan juvenile idiopathic arthritis, systemic lupus erythematosus, dan $\mathrm{BD}(30)$. Mekanismenya antara lain peningkatan kadar myeloperoxidase pada juvenile idiopathic arthritis, kadar Ox-LDL di sirkulasi dan \% LDL pada systemic lupus erythematosus dan penurunan FMD pada BD. Multivariate model analysis menunjukkan bahwa Sjogren syndrome (SS) primer merupakan faktor risiko independent pada penebalan dinding arteri apabila faktor risiko tradisional untuk CVD dapat dikontrol. Studi kontradiksi lainnya menunjukkan bahwa tidak ada perbedaan antara CIMT pasien dengan SS primer dengan pasien kontrol. Selain itu, ada studi yang menunjukkan bahwa perempuan euthyroid premenopausal dengan autoimmune thyroiditis dan predisposisi alergi pada awal masa kanak-kanak CIMTnya meningkat signifikan. Sehingga, penyakit imunologis rheumatoid berhubungan dengan penebalan $\mathrm{CIM}$, dan perlu dilakukan studi untuk meneliti peran dan mekanisme penyakit-penyakit tersebut di atas dalam hubungannya dengan pregresifitas aterosklerosis, dan kontrol standard dan terapi penyakit-penyakit ini sehingga aterosklerosis subklinis dapat dicegah sedini mungkin(31).

\section{Hubungan antara CIMT dengan inflammatory cytokines, lipid peroxidation, anthropometric hemocyte parameters dan penyakit infeksi}

Inflamasi dan lipid peroxidation mempunyai peran penting pada perkembangan aterosklerosis. Walaupun demikian, masih belum diketahui apakah parameter imunologi, inflammatory cytokines, dan lipid peroxidation mempengaruhi CIMT. Inflammatory cytokines seperti CRP dan kadar lipid peroxidation berhubungan dengan peningkatan CIMT. Namun demikian, studi lain menunjukkan bahwa distribusi genotip MnSOD, GSTM 1 dan GSTP1 menurut CIMT, tipe plak atau skor plak tidak berbeda secara signifikan(32). Studi ini menemukan bahwa peningkatan CIMT tidak berhubungan dengan profil cytokine, keseimbangan oxidative atau respons imun pada pasien ALD. Diperlukan penelitian lebih lanjut untuk menemukan hubungan antara CIMT dengan inflamasi dan lipid peroxidation.

Hitung lekosit dan rasio neutrophildengan-lymphocyte dapat digunakan untuk mendiagnosa dan sebagai indikator prognosa aterosklerosis karotis. Hasil studi pada anthropometric hemocyte parameters menunjukkan bahwa lekosit berperan secara independent pada kerusakan dini arteri dan bahwa sel-sel ini menunjukkan adanya penyakit subklinis. Rasio neutrophil-terhadaplymphocyte yang positif dan moderat berhubungan dengan CIMT pada seluruh studi populasi(33). Karena parameter di atas sangat baik dan praktis, maka dapat digunakan untuk evaluasi kemungkinan infeksi yang berhubungan dengan penebalan CIM.

Hubungan antara CIMT dengan penyakit infeksi masih menjadi fokus studi klinis. Studi pendahuluan hasilnya menunjukkan bahwa infeksi HIV merupakan faktor risiko aterosklerosis subklinis pada individu lanjut usia. Pada populasi perempuan dengan HIV di Afrika Selatan, CIMT nya lebih tinggi dan berhubungan dengan faktor risiko CV dibandingkan dengan faktor HIV. Hasil studi lainnya menunjukkan bahwa, usia lanjut, penggunaan protease inhibitor jangka panjang, dan impaired fasting glucose merupakan faktor independent yang berhubungan dengan CIMT pada populasi yang hidup dengan HIV(34). Studi terdahulu, menurut Desvarieux et al (2004) menunjukkan bahwa infeksi H. pylori dengan penggunaan alkohol kronis atau hanya penggunaan alkohol kronis saja, dapat menyebabkan peningkatan CIMT secara signifikan. Selain itu, gigi yang tanggal dan periodontitis jangka panjang berhubungan dengan paparan jangka panjang dengan aterosklerosis subklinis pada laki-laki tetapi tidak pada perempuan(35). Karena hanya sedikit studi yang meneliti hubungan antara inflammatory cytokines, lipid peroxidation, anthropometric hemocyte parameters dan penyakit infeksi dengan CIMT, maka parameter-paramater ini harus menjadi fokus 
studi dengan sampel yang lebih besar untuk verifikasi penemuan ini.

\section{Hubungan antara CIMT dengan sosial ekonomi (socioeconomic position (SEP)) dan stres pekerjaan}

Beberapa studi menemukan bahwa CIMT, SEP, dan stres pekerjaan berhubungan. Walaupun demikian, hasil studi-studi ini tidak konsisten. Ada satu studi yang menyetakan bahwa tekanan pekerjaan berhubungan dengan peningkatan CIMT pada karier valine(Val)/Val, dewasa muda dan stadium nonsimptomatis pada laki-laki(36). Tekanan dalam pekerjaan dapat meningkatkan risiko aterosklerosis subklinis. genotip catechol-0methyltransferase, tidak mempunyai jiwa kepemimpinan (komponen perilaku tipe A), dan peningkatan hyperintense spots dapat menjelaskan hubungan antara tekanan pekerjaan dengan penyakit cerebrovascular(37). Selain itu, CIMT juga berhubungan dengan SEP dewasa dan kerja shift(38). Namun demikian, pekerjaan dengan tekanan yang tinggi dan kontrol pekerjaan yang rendah tidak berhubungan dengan IMT independent dari $\mathrm{SE}$, stres pekerjaan tidak menjelaskan hubungan antara life course SEP dengan CIMT. Tuntutan pekerjaan yang tinggi, High job demands, interaksi sinergis dengan keputusan tingkat rendah, tidak menyebabkan perkembangan aterosklerosis karotis pada lakilaki atau perempuan(39). Mekanisme hubungan ini masih belum jelas. Jadi, kita memperkuat studi pada hubungan antara CIMT dengan SEP dan stres pekerjaan untuk pengukuran prevensi dini dan terapi aterosklerosis.

\section{Hubungan antara CIMT dengan vitamin D}

Hubungan antara vitamin $D$ dengan CIMT masih belum banyak diketahui. Studi yang meneliti antara vitamin $\mathrm{D}$ serum dengan risiko CVD hasilnya masih belum konsisten. Beberapa studi menunjukkan bahwa kadar serum 25hydroxyvitamin D3 (25(OH)D) yang rendah pada masa kanak-kanak berhubungan dengan peningkatan CIMT pada masa dewasa dan subyek dengan serum 25(OH)D $20 \mathrm{ng} / \mathrm{mL}$ mempunyai mean-max progresifitas CIMT lebih rendah setelah terapi dengan atorvastatin, hal ini menunjukkan bahwa defisiensi vitamin $D$ mempengaruhi respons terhadap atorvastatin pada prevensi aterosklerosis(40). Pemberian 25(OH)D bersama dengan obat kolesterol seperti statin dapat membantu prevensi aterosklerosis subklinis. Sebaliknya, kadar serum 25(OH)D tidak berhubungan dengan faktor risiko independent CVD atau CIMT(41). Namun demikian, peningkatan 25(OH)D serum dapat memprediksi aterosklerosis subklinis bukan perokok(42). Karenanya, mayoritas studi tidak mendukung efek protektif vitamin $D$ untuk aterosklerosis subklinis. Diperlukan banyak studi untuk menemukan apakah 25(OH)D mempengaruhi progresifitas aterosklerosis dan peran suplemen $25(\mathrm{OH}) \mathrm{D}$ pada proses aterosklerosis.

\section{Hubungan antara CIMT dengan matrix metalloproteinases (MMPs)}

Bukti menunjukkan bahwa MMPs berperan penting pada aterosklerosis dan merupakan obat baru yang menjanjikan untuk terapi aterosklerosis subklinia. Kadar serum M M P-8, M M P-9, TIMP-1, M M P-9/TIMP-1 dan MM P-10(43) yang tinggi, berhubungan dengan peningkatan CIMT. Karenanya, kadar MMP di atas sirkulasi berguna untuk identifikasi aterosklerosis subklinis. Kesimpulannya, peran MMPs pada aterosklerosis perlu diteliti lebih lanjut.

\section{Hubungan antara CIMT dengan faktor novel dan penyakit lainnya}

Studi terbaru menunjukkan bahwa faktor novel dan penyakit lainnya seperti fungsi hepatorenal, microalbuminuria, kekuatan otot yang rendah, 03, beta-thalassemia minor, defisiensi hormon pertumbuhan dan glaukoma normal-tension, mempunyai hubungan dengan CIMT. Beberapa studi mendapatkan bahwa peningkatan kadar ALT serum (walau pada kadar normal tinggi) berhubungan dengan marker CVD. Walu demikian, ada pula studi dengan hasil yang sebaliknya, yaitu nilai CIMT berdasarkan usia tidak berbeda pada kadar GGT pada laki-laki dan perempuan. Microalbuminuria yang berhubungan dengan CIMT(44), dan kekuatan otot mempunyai hubungan terbalik dan independent dengan CIMT. Paparan 03 pada masa kanak-kanak merupakan faktor risiko novel untuk CIMT pada populasi mahasiswa sehat(45). Selain itu, CIMT yang tinggi berhubungan dengan perkembangan penyakit ginjal kronis, defisiensi hormon pertumbuhan, beta thalassemia minor, 
pre-eclampsia dan menopause(46). Namun demikian, studi terbaru tidak menunjukkan adanya hubungan peningkatan kadar hormon parathyroid (PTH) dan normal-tension glaucoma dengan perubahan CIMT. Jadi, hubungan antara CIMT dengan penyebabpenyabab di atas masih memerlukan verifikasi lebih lanjut.

\section{KESIM PULAN}

Review literatur terbaru menunjukkan adanya preliminary evidence hubungan antara CIMT dengan faktor risiko tradisional dan faktor risiko novel CV, hal inoi menunjukkan bahwa CIMT merupakan prediktor klinis yang baik untuk aterosklerosis dini, dan pengukuran CIMT nyaman, sederhana dan praktis. Namun demikian, kebanyak studi bersifat retrospektif, dan masih belum banyak studi skala besar yang prospektif dan banyaknya metode pengukuran yang digunakan oleh peneliti membatasi analisis. Penentuan nilai CIMT (maximum CIMT, mean CIMT, minimum CIMT, arteri karotis kiri atau kanan) yang berhubungan dengan aterosklerosis dini, perlu disamakan. Penemuan ini mengingatkan kita bahwa prevensi dini aterosklerosis harus

dimulai dari saat bayi untuk mendeteksi keadaan kesehatan yang abnormal. Selanjutnya diperlukan studi yang fokus pada faktor risiko tradisional dan faktor risiko novel. Karena tubuh manusia merupakan suatu kesatuan utuh, maka semua jenis keadaan kesehatan yang abnormal dapat membahayakan seluruh tubuh, termasuk sistem pembuluh darah. Karenanya, kita harus lebih memperhatikan keadaan kesehatan tubuh, dan untuk mencegah aterosklerosis pembuluh darah dan aterosklerosis dini, kita harus memperkuat terapi keadaan kesehatan yang abnormal dan penyakit.

\section{DAFTAR PUSTAKA}

1. Corrales A, Parra JA, Gonzale-Juanatey C, Rueda-Gotor J, Blanco R, Llorca J, et al., 2013. Cardiovascular risk stratificationin rheumatic diseases: carotid ultrasound is more sensitive than Coronary Artery Calcification Score to detect subclinical atherosclerosis in patients with rheumatoid arthritis. Ann Rheum Dis. 72(11): 1764-7170.
2. Onut R, Balanescu AP, Constantinescu D, Calmac L, Marinescu M, Dorobantu PM, 2012. Imaging atherosclerosisby carotid intima-media thicknessin vivo: how to, where and in whom? Maedica (Buchar). 7(2): 153-62.

3. Qu B and Qu T, 2015. Causes of changes in carotid intima-media thickness: a literature review. Cardiovascular Ultrasound. 13:46.

4. Han L, Bai X, Lin H, Sun X, Chen X, 2013. Gender differences in the relationship between age-related carotid intima-media thickness and cardiac diastolic functionina healthy Chinese population. J. Card Fail. 19(5):325-32.

5. Ceponiene I, Klumbiene J, TamuleviciutePrasciene E, Motiejunaite J, Sakyte E, Ceponis J, et al., 2015. Associations between risk factors in childhood (12-13 years) and adulthood (48-49 years) and subclinical atherosclerosis: the Kaunas Cardiovascular Risk Cohort Study. BMC Cardiovasc Disord. 15: 89.

6. Feairheller DL, Dia KM, Kashem MA, Thakkar SR, Veerabhadrappa P, Sturgeon $\mathrm{KM}$, et al., 2014. Effects of moderate aerobicexercise training on vascular heal than $d$ blood pressure in African Americans. J. Clin. Hipertens (Greenwich). 16(7):504-10.

7. Taylor BA, Zaleski AL, Capizzi JA, Ballard KD, Troyanos C, Baggish AL, et al., 2014. Influence of chronic exercise on carotid atherosclerosis in marathon runners. BMJ Open. 4(2), e004498.

8. Chen $\mathrm{Y}$, Xiong $\mathrm{H}, \mathrm{Wu} \mathrm{D}$, Pirbhulal $\mathrm{S}$, Tian $\mathrm{X}$, Zhang R, et al, 2015. Relationship of shortterm blood pressure variability with carotid intima-media thickness in hypertensive patients. Biomed Eng Online. 14:71.

9. Bianga Katchunga $P$, Mongane Irenge J, Canwa R, M atabaro A, Nsimire S, Kabunga Q., 2014. Carotid intima-media thickness in the Congolese hypertensive in South Kivu. Ann Cardiol Angeiol (Paris).

10. Bosevski M, 2011. Carotid IMT, in type2 diabetic patients: a survey on factors of influence. Prilozi. 32(2): 289-97. 
11. Pirro M, Vaudo G, Lupattelli G, Pasqualini L, Mannarino MR, Schillaci G, et al. 2013. On-treatment $\mathrm{C}$-reactive protein and $\mathrm{HDL}$ cholesterol levels in patients at intermediate cardiovascular risk: impact on carotid intima-media thickness. Life Sci. 2013;93(8):338-43.

12. Gruszfeld D, Weber M, Nowakowska-Rysz $M$, Janas R, Kozlik-Feldmann R, Xhonneux $A$, et al. Protein intake in infancy and carotid intima media thickness at 5 yearsa secondary analysis from a randomized trial. Ann Nutr Metab. 2015;66(1):51-9.

13. Walus-Miarka M, Wojciechowska W, Miarka $P$, Kloch-Bade, ek M, Wozniakiewicz E, Cz arnecka $D$, et al., 2013. Intima-media thickness correlates with features of metabolic syndrome in young people with a clinical diagnosis of familial hypercholesterolaemia. Kardiol Pol. 71(6):566-72.

14. Bos S, Duvekot MH, Touw-Blommesteijn $A C$, Verhoeven AJ, Mulder MT, Watts GF, 2015. plaques and carotid intima media thickness in statin-treated patients with familial hypercholesterolemia. Atherosclerosis. 242(1):226-9.

15. Mostaza JM, Laho C, Salinero-Fort MA, deBurgos-Lunar $C$, Laguna F, Estirado $E$, et al, 2015. Carotid atherosclerosis severity inrelation to glycemic status: a cross sectional population study. Atherosclerosis. 242(2):377-82.

16. Shimizu $Y$, Nakazato $M$, Sato $S$, Koyamatsu J, Yamanashi H, Nagayoshi M, et al., 2015. Association between hemoglobin Alc and carotid atherosclerosis in rural community-dwelling elderly Japanese men. JPhysiol Anthropol. 34(1):16.

17. Lorenz MW, Price JF, Robertson C, Bots ML, Polak JF, Poppert H, et al., 2015. Carotid intima media thickness progression and risk of vascular events in people with diabetes: results from the PROG-IMT Collaboration. Diabetes Care. [Epub ahead of print].

18. Shimizu Y, Sato S, Koyamatsu J, Yamanashi H, Tamai M, Kadota K, et al., 2014. Subclinical carotid atherosclerosis and hyperuricemia in relation to renal impairment in a rural Japanese population: the Nagasaki Islands study. Atherosclerosis. 233(2):525-9.
19. Lee MJ, Shin DH, Kim SJ, Oh HJ, Yoo DE, Kim JK, et al., 2012. Visceral fat thickness is associated with carotid atherosclerosis in peritoneal dialysis patients. Obesity (Silver Spring). 20(6):1301-1307.

20. Barcellos CR, Lage SH, Rocha MP, Hayashida SA, Baracat EC, Romano A, et al., 2013. Polycystic ovary syndrome and obesity do not affect vascular parameters related to earl atherosclerosis in young women without glucose metabolism disturbances, arterial hypertension and severe abnormalities of lipid profile. Gynecol Endocrinol. 29(4):370-4.

21. Rampersaud E, Bielak LF, Parsa A, Shen H, Post W, Ryan KA, et al., 2008. The association of coronary artery calcification and carotid artery intima-media thickness with distinct, traditional coronary artery disease risk factors in asymptomatic adults. AmJ Epidemiol. 168(9):1016-23.

22. Masi S, D'Ajuto F, Martin-Ruiz C, Kahn T, Wong A, Ghosh AK, et al., 2014. Rate of telomere shortening and cardiovascular damage: a longitudinal study in the 1946 British Birth Cohort. Eur Heart J. 35(46):3296-303.

23. Ragab SM, Safan MA, Badr EA, Ebeid OM ., 2014. Haptoglobin genotypes polymorphism as a risk factor for subclinical atherosclerosis in beta thalassemia major children; a single center Egyptian study. Hematology. [Epub ahead of print].

24. Cunnington MS, Mayosi BM, Hall DH, Avery PJ, Farrall M, Vickers MA, et al., 2009. Novel genetic variants linked to coronary artery diseaseby genome-wide association are not associated with carotid artery intima-media thickness or intermediate risk phenotypes. Atherosclerosis. 203(1):41-4.

25. Sinha PK, Santr G, De D, Sah A, Biswas K, Bhattachary P, et al., 2012. Carotid intimamedia thicknessin type2diabetes mellitus patients with cardiac autonomic neuropathy. JAssoc Physicians India. 60:14-8.

26. Ikeda N, Gupta A, Dey N, Bose S, Shafique S, Arak T, et al., 2015. Improved correlation between carotid and coronary atherosclerosis SYNTAX score using automated ultrasound carotid bulb plaque IMT measurement. Ultrasound Med Biol. 41(5):1247-62. 
27. Pacifico L, Anania C, Martino F, Cantisani V, Pascone R, Marcantonio A, et al., 2010. Functional and morphological vascular changes in pediatric nonalcoholic fatty liver disease. Hepatology. 52(5):1643-51.

28. Park YB, Ahn CW, Choi HK, Lee SH, In BH, Lee $\mathrm{HC}$, et al., 2002. Atherosclerosis in rheumatoid arthritis: morphologic evidence obtainedby carotid ultrasound. Arthritis Rheum. 46(7):1714-9.

29. Troitzsch P, Paulista Markus MR, Dorr M, Felix SB, Junger $M$, Schminke $U$, et al., 2012. Psoriasis is associated with increased intima-media thickness-the Study of Health in Pomerania (SHIP). Atherosclerosis. 225(2):486-90.

30. Gravani F, Papadaki I, Ant pa E, Ne os A, Masselou K, loakeimidis D, et al., 2015. Subclinical atherosclerosis and impaired bone health in patients with primary Sjogren's yndrome: prevalence, clinical and laboratory associations. ArthritisResTher. 17(1):99.

31. Evelein AM, Visseren FL, van der Ent CK, Grobbee DE, Uiterwaal CS., 2014. Allergies are associated with arterial changesin young children. Eur]Prev Cardiol. [Epub ahead of print].

32. Loimaala A, Rontu R, Vuori I, Mercuri M, Lehtimaki T, Nenonen A, et al., 2006. Blood leukocyte count is a risk factor for intima-media thickening and subclinical carotid atherosclerosis in middle-aged men. Atherosclerosis. 188(2):363-9.

33. Schoffelen AF, de Groot E, Tempelman HA, Visseren FL, Hoepelman Al, Barth RE. 2015. Carotid intima media thickness in mainly female HIV-infected subjects in rural South Africa: association with cardiovascular but not HIV-related factors. Clin Infect Dis. [Epub ahead of print].

34. Qu B, Su J, Wang Z, Wang Y, Han X, Wang $H$, et al., 2015. Effect of $H$. Pylori infection on cytokine profiles and oxidative balance in subjects with chronic alcohol ingestion. PLoS One. 10(6), e0129352.

35. Hintsanen $M$, Elovainio $M$, Puttonen $S$, Kivimaki $M$, Lehtimaki $T$, Kahonen $M$, et al., 2008. Val/Met polymorphism of the COMT gene moderates the association between job strain and early atherosclerosis in young men. J Occup Environ M ed. 50(6):649-57.
36. Michikawa $T$, Nishiwaki $Y$, Nomiyama $T$, Uemura T, O'Uchi T, Sakurai H, et al., 2008. Job strain and arteriosclerosis in Three different $t$ pes of arteries among male Japanese factor workers. Scand J Work Environ Health. 34(1):48-54.

37. Camelo LV, Giatti L, Chor D, Griep RH, Bensenor IM, Santos IS, et al., 2015. Associations of life course socioeconomic position and job stress with carotid intima-media thickness. The Brazilian Longitudinal Study of Adult Health (ELSABrasil). Soc Sci Med. 141:91-9.

38. Rosvall M, Ostergren PO, Hedblad B, Isacsson SO, Janzon L, Berglund G., 2002. Work-related psychosocial factors and carotid atherosclerosis. Int] Epidemiol. 31(6):1169-78.

39. Juonala M, Voipio A, Pahkala K, Viikari JS, Mikkila V, Kahonen M, et al., 2015. Childhood $25-\mathrm{OH}$ vitamin D levels and carotid intima-media thicknessin adulthood: the cardiovascular riskin young Finns study. JClin Endocrinol Metab. 100(49):1469-76.

40. Baker CP, Kulkarni B, Radhakrishna KV, Charyulu MS, Gregson J, Matsuzaki M, et al., 2015. Is the Association between Vitamin D and Cardiovascular Disease Risk Confounded by Obesit? Evidence from the Andhra Pradesh Children and Parents Stud (APCAPS). PLoSOne. 10(6), e0129468. doi:10.1371/journal.pone.0129468eCollec tion2015.

41. Reis JP, von M Ã $1 / 4 h$ len $D$, Michos ED, Miller 3rd ER, Appel LJ, Araneta MR, et al., 2009. Serum vitamin $D$, parathyroid hormone levels, and carotid atherosclerosis. Atherosclerosis. 207(2):585-90.

42. Sander PO, Meurman JH, Jogestrand T, Nowak J, Soder B., 2009. Matrix metalloproteinase- 9 and tissue inhibitor of matrix metalloproteinase-1 in blood as markers for early atherosclerosis in subjects with chronic periodontitis. JPeriodontal Res. 44(4):452-8.

43. Kong X, Jia X, Wei Y, Cui M, Wang Z, Tang $L$, et al., 2012. Association between micro albuminuria and subclinical atherosclerosis evaluatedby carotid artery intima-media in elderly patients with normal renal function. BMC Nephrol. 13:37. 
ISSN 1978-2071 (Print); ISSN 2580-5967 (Online) Jurnal IImiah Kedokteran Wijaya Kusuma 6 (1) : 34-44

44. Aykas F, Solak Y, Erden A, Bulut K, Dogan S, Sarli B, et al., 2015. Persistence of cardiovascular risk factors in women with previous preeclampsia: a longterm followup study. JInvestig Med. 63:641-5.

45. Shimiu $M$, Furuso $N$, Mitsumoto $F$, Takaama K, Ura K, Hiramine S, et al., 2015. Subclinical carotid atherosclerosis and triglycerides predict the incidence of chronic kidney disease in the Japanese general population: results from the Kyushuand Okinawa Population Study (KOPS). Atherosclerosis. 238(2):207-12.

46. Bossuyt J, Vandekerckhove G, De Backer TL, Van de Velde S, Azermai M, Stevens $A M$, et al., 2015. Vascular dysregulation in normal-tension glaucoma is not affected by structure and function of the microcirculation or macrocirculation at rest: a case-control study. Medicine (Baltimore). 94(2), e425. 